\title{
(Re)conceptualizing Difference in the Context of the Acting Subject's Identity ${ }^{1}$
}

\begin{abstract}
What is the source and the effect of the acting subject's identity? This question refers to difference, but not in its usual conceptualization, synonymous with a border and the need to maintain or transcend it. By reconceptualizing difference, which I see as "re-creating" the meaning and linking it with "added" meanings, this article restores its original load (importance) in being an acting subject, mediated in otherness. For this purpose, the différance of Jacques Derrida is invoked and his statements about it combined with those of other philosophers, in whom I found what is related and/or complementary and extends not only Derrida's thought, but that which constitutes the main theme of this article. On the one hand, otherness is an impulse to the "work" of the difference, and on the other hand, it is its effect. What is the role of the "work" of the difference in creating the identity of the acting subject? In connection with the "shift" of the effect of its work - otherness, into the area of the identity of the acting subject, can this subject say about itself: this is still me? In this context, what is responsive ethics, which, I believe, should be included in the contemporary humanistic and social discourse about the subject?
\end{abstract}

Keywords: otherness, difference, identity, acting subject, responsive ethics.

\section{(Re)konceptualizacja różnicy w kontekście tożsamości podmiotu działającego}

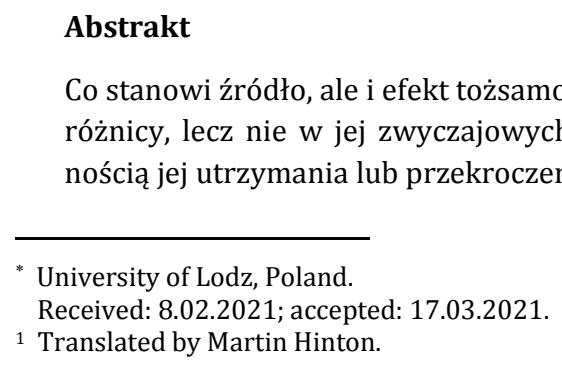

\footnotetext{
* University of Lodz, Poland.

Received: 8.02.2021; accepted: 17.03.2021.

1 Translated by Martin Hinton.
}

Co stanowi źródło, ale i efekt tożsamości podmiotu działającego? Pytanie to odsyła do różnicy, lecz nie w jej zwyczajowych ujęciach bliskoznacznych z granicą i koniecznością jej utrzymania lub przekroczenia. Poprzez (re)konceptualizację różnicy, którą 
ujmuję jako „od-tworzenie” znaczenia i powiązanie go ze znaczeniami „dodanymi”, w artykule przywraca się jej źródłową nośność (ważność) w byciu podmiotem działającym, zapośredniczonym w inności. W tym celu przywołana zostaje différance Jacquesa Derridy i - w dalszej kolejności połączenie jego wypowiedzi o niej z innymi filozofami, u których odnalazłam to, co pokrewne i/lub uzupełniające i rozszerzające nie tyle samą myśl Derridy, ile to, co stanowi główny wątek niniejszego artykułu. Inność z jednej strony jest impulsem do „pracy” różnicy, z drugiej zaś jej efektem. Jaka jest rola „pracy” różnicy w tworzeniu się tożsamości podmiotu działającego? Czy w związku z „przemieszczeniem” efektu jej pracy - inności, w obszar tożsamości podmiotu działającego, podmiot ten może o sobie powiedzieć: oto wciąż Ja? Czym w tym kontekście jest etyka responsywna, którą - zdaniem autorki artykułu - należy wpisać we współczesny dyskurs humanistyczno-społeczny na temat podmiotu?

Słowa kluczowe: inność, różnica, tożsamość, podmiot działający, etyka responsywna.

\section{Introduction}

In contemporary humanistic and social discourse, which builds upon postmodernism, it is difficult to maintain the ethical validity of abstract-universal approaches to the subject with the Cogito at the centre ${ }^{2}$. These views of the subject have been indicted by postmodernism as well as anti- and new anthropocentrism movements. The subject was not so much rejected as "turned", or rather "shifted" to such an area of being that is not reduced only to cognition and thinking. And if one talks about a cognizing subject, it is more and more often in opposition to the principles of modern assumptions of cognition which define it as "disembodied, impersonal, static, external and neutral (disinterested or disengaged)" (Nycz 2017: 10). Therefore, as Ryszard Nycz writes, in the new humanities, the project which he constructs, research is conducted on the basis of different assumptions: "embodied cognition, personalized (participating), actively working (cognitively intervening),

\footnotetext{
${ }^{2}$ In the contemporary humanistic and social discourse, built on postmodernism, I include the pedagogical discourse. In the Polish area, the identity of the subject was expressed, among others, by Tomasz Szkudlarek (2008, 2012a, b, 2017), Astrid Męczkowska (2006), and Maria Reut (2010). I am pointing to the authors whose statements on this subject are close to me, and at the same time inspire me to seek answers to the question about the "specification" of the subject and its identity. I see this "specification" in the category of action - so in the article I speak about an acting entity, which as such is always in relation to the Other. Making an allusion at this point to the title of the famous book by Milan Kundera (The Unbearable Lightness of Being), the "unbearable" necessity of a relationship with the Other/s characterizes the subject of various social professions, including pedagogical professions. I do not focus on this thread in this article. My intention is to show the source of the change in the identity of the acting subject - what is "invisible" in this process, but also what is "unnecessary", thus treating the change itself as (only) possible. At the same time, I assume that for modern pedagogy, the discourse about the subject in which a significant shift of emphasis has been made and is taking place is important in determining its identity and scientific status and the type of recommendations for various fields of practice, which has already been done by the above-mentioned authors. A separate study would be required to indicate the pedagogical implications of the considerations presented in this article.
} 
penetrating inside the examined problem environment and situated (engaged)" (ibidem: 11).

The philosophy of the times of crisis of modernity and postmodernity, contemporary phenomenology, with Husserl still resonating, and French poststructuralism, as well as French and Italian hermeneutics (and within it of weak thought - close to my mental sensitivity) ${ }^{3}$, directs the discourse on the subject (vel or versus subjectivity) into the regions of its reinterpretation and reveals the importance of the Other and otherness, experience and ethics for its existential condition, emphasizing it as its main feature ${ }^{4}$.

Referring to the figure of Gaston Bachelard's "epistemological profile", I treat my statement as a profile conceptualizing the category of a subject acting on the basis of its (re)contextualization (Bachelard 2000: 43). In this statement, I write the Derridian différance, which I consider significant in the context of the identity of the acting subject. It is customary to associate the identity of the subject with the category of difference - I am different from others and then I am identical with myself. Also, who I am now comes to the fore when I can point out the difference between me now and me before. However, I "read" the difference differently - away from its usual depictions synonymous with a border and the need to maintain or exceed it in order to be able to differ from the Others and thus be identical (with myself).

Adopting the framework of the contemporary humanistic and social discourse about the subject (vel or versus subjectivity) with the emphasis on ethics as its main feature, my statement is a form of reflection on the genealogy of ethics of the one who acts, i.e. in relation to the Other, as well as to himself as Different. This reflection was based on the feeling that there is a need to problematize the longunproblematic (because of "well-worn" meanings, also when one talks about a multitude of meanings - but always already assigned) or niche (therefore not problematic) or borderline and marginalized (because too problematic) areas of reflection about the subject acting vel relational - the one who enters into specific relations with the Other. And this is about such relationships that are oriented towards the Other. The reflection on the subject defined in this way may not be fully adequate to the living being, which I have defined as the acting subject. Why? As an author, I am steeped in such discourses about the subject, which establish it as a "present point" and "view it" through the prism of its relationship with the Other, configuring its entanglement in ethics - ethics as a way of being of difference and towards it. So I am defined by those discourses in which the subject regains its

\footnotetext{
3 Michel Foucault, Jacques Derrida, with the historic precedence of Jacques Lacan. Among the Italian hermeneuts representing the so-called weak thought, one should point to Gianni Vattimo, Pier Aldo Rovatti, Maurizio Ferraris (see Choińska 2014; Surma-Gawłowska, Zawadzki 2015).

${ }^{4}$ Cf. with the ethical turn in the humanities. Its synthetic approach is presented by Anna Burzyńska in the book Deconstruction, Politics and Performance in the subsection Ethics in Times of Uncertainty (Burzyńska 2013: 50-58).
} 
proper place by recognizing its fragility vel non-permanence (versus self-confidence and monumentality, i.e. always-being-the-same). My statement is the mental design of an acting subject whose identity is capable of formation "provided" that subject takes into account the genealogy of ethics of itself as the acting subject.

\section{The acting subject vel the relational subject}

An acting subject is a subject that defines itself through its being-in-the-world in its various spheres, where being is a form of expression/speaking 5 . The phrase used: expression/speaking is metaphorical. When deciding on it, I refer to, inter alia, a hermeneutic category of utterance which is the result of understanding (oneself) of an historical nature.

As a subject of expression/speaking, I am an acting subject - therefore I am thinking, speaking, writing, painting, dancing, playing, doubting... et cetera. I am the acting one who is living in the here now. As I, I express myself in all spheres of my being. At this point it is worth recalling Paul Ricoeur, for whom, for example in the situation of a conversation, "'I' is a wandering term, a position that can be occupied by many virtual and substitutable speakers" (Ricoeur 2005: 84). By using the personal pronoun I mean myself, but the Other Self also has this ability to refer to itself. For Ricoeur, 'I' points to one person - his individuality, non-substitutability and uniqueness. The other is not only the subject of my thoughts, emotions, fears, et cetera - just as I am the subject of thoughts, emotions, fears, et cetera. However, the I understood in this way is mediated in something beyond itself - for Ricoeur it is about acting in its diversity, within which being in a relationship with the Other, also with oneself as another, or rather in the character of another, was particularly significant. And only this leaning towards ..., which we find in the very potency of action, gave the opportunity for differentiation - the separation of my Self from the Other Self. Ricoeur wrote: "it is being oneself both in its difference to being the same and in its dialectical connection with otherness" (ibidem: 503).

The difference constitutes my subjectivity, which is expressed in the feeling of being the only owner of expressing/speaking myself - this is me. Subjectivity understood in this way would be the effect of differentiating my and other subjectivities with clearly defined boundaries ${ }^{6}$. However, for Jacques Derrida,

\footnotetext{
${ }^{5}$ Expression/speaking as a way to understand oneself and its effect corresponds to the concept of narrative identity by Paul Ricoeur, which is a mental background for the issues raised in this text - "the statement builds the identity of a character, which can be called a narrative identity, building the identity of the story being told" (Ricoeur 2005: 245). I wrote more on this topic earlier (Walczak 2011).

${ }^{6}$ By the way, the dependence of identity only on oneself (is it possible at all?) Indicates me as an authority for myself, which Erich Fromm would describe as irrational, because it is based on self-love of who someone is (who you are). Being an authority for oneself, however, is lined with a fear of the consequences of confronting oneself - a fear of the disintegration of what is already familiar to oneself and which gives a sense of certainty and security (cf. Fromm 1994: 117-141).
} 
whose deliberations on the difference (différance) ${ }^{7}$ became an inspiration for me to rethink the identity of the acting subject, in saying: "this is this" or "this means this", we immobilize the game of meanings - we position, essentialise, substantiate (Derrida 2007: 44). Reducing the identity of the acting subject to a simple being subjectivity - the I acting would be precisely to immobilize its possible meanings.

I place the acting subject first as "opposite" to the Other in their actual being8. I treat their actual being as their primary structure of life, usually associated with the presence in everyday life of what we perceive and participate in. It is impossible to pass by it - you are in it. Actuality, through "its" time and place of events, it is both accidental and unique, because it is temporal and local (cf. Potępa 2004: 59-74). In fact, the acting subject is here now and next to the others - it is a timespace framework that is filled with the presence of subjects "opposite" to each other. The acting subject is, therefore, a relational subject - it is in a relationship with the Other, also with itself as the Other (cf. Warmbier 2019: 23-52). At the first level of this relationship, I perceive and relate to the presence of the Other through sensuality. And so, for example, when I see him, I look at him, that is, I observe him in many possible ways: I embrace him with my gaze, I watch him, I stare at him, I measure him with my eyes, I observe him. Hearing him "catch my ear" with what he says, even if he is not speaking to me, I register his presence in the auditory context and distinguish him from the presence of another subject, I listen and hear what he says, and maybe I also eavesdrop on him as a speaker. Being "opposite" to him, I am with him in some space - in the physical sense - and at the time specified by the clock. However, this relationship is not one-sided. The presence of the Other means that he also remains in a relationship with me - neither is he anonymous (he is the Other), nor does he remain neutral (after all, his position and action, as well as my position and action, are "opposite", belong to a shared time space). Therefore, being in a relationship with the Other is not only up to me. The presence of the Other and being in a relationship with him - if only by being "opposite" to him, which, following Martin Buber (Buber 1992; cf. Glinkowski 2011: 93-102), belongs to the zone of obviousness - questions subjectivity as being the same (and sometimes the same) without the Other being part of this being. Another enters the experience of me as an acting subject through his presence. And although I am the owner of myself - I speak as I, the presence of the Other and the relationship with him are part of this expression. As an acting subject - acting also with the Other, and therefore in relation to him - I need recognition of my presence by

\footnotetext{
7 To distinguish the meanings of the word difference that Jacques Derrida gives it, I write it in italics. When deciding to use différance as a difference in the article, I want to point to its different - but equally relevant - conceptualization in the context of the emerging identity of the acting subject. The use of différance as a difference was accompanied by the words of Renaud Barbaras: "(...) the very possibility of using a word in areas other than its usual one reveals the depth of its own meaning which should be nourished by thinking" (Barbaras 2017: 80).

${ }^{8}$ Speaking of factuality, I stop at the "obvious" approach to it, close to the colloquial.
} 
the Other, just as the Other needs recognition of his presence by me. Recognition is not yet being in relation to oneself, it is recognizing one another in the factuality in which one is - recognizing that in my being an acting or relational subject, the Other is also present. Me and the Other are different to each other - which means that the basis of this relationship is symmetry, not asymmetry ${ }^{9}$ I and the Other are irreducible in our otherness through the inability to replace each other in experiencing being-in-the-world. Each experience, including the experience of the Other, is originally my experience - also the experience of the Other is originally just his experience. However, in the fact that this is an experience for me, so his experience is for him, that is, in some form of returning the experience to its owner, the Other is present.

Does this not undermine the identity of the subject, which is constituted in the original, direct relation of the self to itself? Does the first-person singular personal pronoun that is grounded in Western philosophical thought by a preference for subjectivity in the form of a monad and in the character of self-presentation: "here is I" still have the power to indicate the identity of the acting subject: here I act - always this I? ${ }^{10}$ Above, these questions have already been answered by pointing to the Other, who is harnessed to the presence of me as the Other for him, but also for himself as the Other. However, is the presence of the Other this distinctive chord of sounds: I, the Other, I and the Other?

\section{Difference - the "absent" source of becoming an acting subject}

The acting subject, i.e. the subject in relation to the Other, does not act without a reason. Here, it is not about such an approach to the cause that reveals the intentionality of an action that stretches between "why" I act and "what" I act for. I assume that the cause of the subject's action is a difference which, in reference to the Derridian différance, would be primal to the intention of the action.

For Derrida, the desire to be there - first and foremost to be there - is the essence of the desire itself. Therefore, it cannot be destroyed. But what stimulates the desire itself, which usually comes from the absence of what is desired, as well as when there is a threat of the absence of something to which, for example, one is

\footnotetext{
${ }^{9}$ It is noteworthy at this point that the difference between, for example, Derrida and Ricoeur, and Lévinas, for whom the Other is always "higher" than the Identical by calling to that which cannot be answered. It is subject to the call of the Other Identity and surrenders to it. More about French heterology and the differences within it can be found in the book by Michał Kruszelnicki (2008).

${ }^{10} \mathrm{Cf}$. Robert Piłat in the text Subjectivity as a relation of a person to his own future presents, after Hector-Neri Castañeda, semantic ambiguities in statements about himself using the personal pronoun I as well as its empirical forms, and in conclusion he writes: "the subject turns out to be elusive in typical linguistic constructions used to talk about oneself - the expression 'I' seems to be devoid of reference, and its meaning is heterogeneous and ad hoc (...)" (Piłat 2016: 58).
} 
attached? Derrida points to différance in the womb of the Same - in the womb of a single, identical person.

Différance is what "is not, does not exist, is no being (...), has neither existence nor essence" (Derrida 1978: 378-379). In Bogdan Banasiak's Polish translation of Derrida's of Grammatology, différance is 'różNICość' ('Nic' in Polish meaning 'nothing'), where NOTHING is what is concerned (Derrida 1999) - nothingness, non-presence, lack. NOTHING - the core of difference - "holds" the movement of being the Same, although it would seem that NOTHING can do anything. But it is NOTHING that divides the being the Same as a whole - it unseals it, allowing in its gaps the appearance of otherness and then invention in its creation.

The difference - in the context of these considerations - would therefore be the absence in being an acting subject and at the same time the "constitutive causation" of its identity (Derrida 2007: 15). Derrida wrote: "It could be shown that any designation of a foundation, principle or centre has always signified the invariant of a presence (eidos, arche, telos, energeia, ousia [essence, existence, substance, subject], aletheia, transcendentality, conscience, God, man, etc.)" (Derrida 2004: 485). If, for him, the difference is "constitutive, productive and source causation", then it is nevertheless an "invariant of some presence", a condition other than presence as fact - other than substantional presence (Derrida 1999: 13).

Have we come closer to what the difference means in the context of the identity of the acting subject? I shall ask another question: what is the share of difference - something that is only an "invariant of some presence" - in the "production" of otherness on which the identity of the acting subject depends? The premise shines through in this question that the Derridian différance, even being absent, has a creative power of itself. There is, however, some sort of prejudice against the difference. Derrida asks: "What is it, what is different, or who is different?", and this question is not about what is the difference, because we already know that it is not a being: position, essence, substance (Derrida 1978: 384). It is otherness that cannot be enclosed in a package of its meanings. However, it is possible to indicate its position in relation to the difference - it is the unforeseeable prejudice of "constitutive causation" - the difference and at the same time the effect of its "work". For otherness, "no horizon of expectations seems obvious, ready and available" (Derrida 1996: 98). It is not obvious, and thus visible, it is not a monadic construct and does not lend itself to sensual grasping. The Otherness does not come from the outside either, although the presence of the Other and the necessary being "opposite" to it can move it. Otherness can only manifest itself through spacing, pause, temporal and spatial gap - between where something is here (what/who I am here) and what is not yet somewhere (what/who I am not there) ${ }^{11}$. In the

\footnotetext{
${ }^{11}$ For Bernhard Waldenfels, what is strange, and what we encounter in its experience, is not dependent on good or bad will, because it "breaks the expectations of meaning and stipulating rules that feed on the will". It is what cannot be wanted - what is alien "turns out to be something impossible, something that shakes up existing possibilities and puts them into question" (Waldenfels 2009: 52).
} 
opening of the transition of otherness, the 'game-of-delay-for-difference'12 begins, anticipating its 'work' in the horizon that makes it impossible to close otherness (by continuing to procrastinate) - what is different - in ready-made meanings and assimilate them. The meanings are still absent - the "work" of the difference foreshadows the possible meanings of a potential presence rooted in its absence.

Derrida, locating otherness through the metaphor of spacing, creating a time and space interval in the womb of the Same, draws attention to its prejudice in relation to difference. Otherness cannot, therefore, be the difference, nor can it (originally) establish it. It "puts" the difference in motion through that gap that separates temporality and spatiality in their inseparability from what is not yet so.

Otherness "introduces" a difference to the area of the identity of the acting subject. The difference, on the other hand, "sets" in motion a possible change (in) the identity of the acting subject by "producing" otherness. In the womb of the Same - in the womb of identity - the "work" of the difference takes place, on the basis of which, using the words of Jacques Lacan at this point, "the subject first receives his own message in an inverted form" - "it is from the Other that the subject receives his own message" (Lacan 2004; Choińska 2014: 133). I receive a message from you - myself as becoming the Other, changing I, or from the I on the verge of change - "inexpressible 'Who am I?' To which, before being spoken, he replies, certain 'You are' (...)" (ibidem: 133). Derridian spreading foreshadows me as you from delayed, deferred, "not yet" time-space, which sends me (then to whom?) a message of possible change. There is no certainty, however, that the change (as a result of the "work" of the difference) will take place, and even if it does, when, and that it will be a change for the better ${ }^{13}$. The "work" of difference creates the possibility of changing the meanings of who I am as an acting subject - why, what for and how I act. The possibility here would be the potential of the acting subject, which is triggered by his experience of otherness as a result of the "work" of the difference and responding to it, about which I shall write in the last part of the article. And what does otherness mean as a result of the "work" of difference?

\section{The "work" effect of the difference}

Otherness - the otherness of the Other, as well as the otherness of I as the Other, initiates the crossing of the relationship between I and the Other from the first level, which is a mutual connection (affinity) in fact with the relationship between

\footnotetext{
12 The interpretation of différance as "game-of-delay-for-difference" was proposed by Stanisław Cichowicz (Cichowicz 1975; Marzec 2011: 265).

${ }^{13}$ In this article, I do not elaborate on the connotation of change in the context of the acting subject's identity. However, I have in mind a wide range of connotations, in which I also take into account the concept of positive disintegration of the classic writer of Polish psychology, Kazimierz Dąbrowski (Dąbrowski 1979).
} 
I and the Other from the second level, which is the relationship to the otherness of the Other and I myself as the Other - referring to it, responding to it. To refer to the Latin root word (relatio), the account would be a "report" to the Other, to oneself as Another, about the "work" of the difference. In the feeling of the acting subject, he is "marked", "appointed", "summoned", "called", "invited", "provoked", "forced", "drawn", "attracted" et cetera to the relationship between him and the Other on the second level. The point, however, is that in this way the acting subject becomes deluded. The Derridian "work" of difference takes place in the womb of The Same, so otherness cannot join it from outside, since it is its effect. But at the same time, otherness is a condition of the Same-One, as Ricoeur convinces us about "being oneself", which "presupposes otherness to an extent so deeply intrinsically that one cannot be thought without the other" (Ricoeur 2005: 9).

Therefore, otherness begins in myself, and as Bernhard Waldenfels says ${ }^{14}$, I answer to myself what otherness means (for me) - also the otherness of the Other and the revealing otherness of myself as the Other (Waldenfels 2009: 52). Following Waldenfels's footsteps, I shall point to the binary charge of the potentiality of otherness. For Waldenfels, I absorb otherness into myself - I absorb it to the point of appropriation and ownership, or I get used to it to the point of abandoning myself to it. In the first case, I "introduce" otherness into my home - identity, pointing to its place in it. In the second, feeling uncomfortable in my own home, I "rearrange" it until I "move out" of it. Suspension of the current feeling of "being myself" - even in the form of reflection on who I am no longer and who I am not yet - may make it difficult to return home, especially since one does not return to the same house. In relation to otherness, it is not about strengthening my position as I know me, but about changing myself in the face of otherness that "threatens" my home. I change - I become different, for example, to protect myself from the temptation of being absorbed by an otherness that I do not recognize. When I leave my home, "I rather slip into otherness" and then "exaggerated identification begins, which is a temporary remedy against an 'identity disorder"” (Farred 2016: 305) ${ }^{15}$. Summing up only the meanings of otherness signalled here, it

\footnotetext{
${ }^{14}$ Strangeness to Waldenfels. I shall return to the topic of responding to otherness in the last part of the article.

15 The words in quotation marks were taken from Grant Farred, who writes about how, in the context of being a human - a Jew - from Algeria, to which Derrida refers in Monolingualism, this monolingualism can be interpreted all the way to Derridian "identity disorder". And he writes: "Monolingual writing conceived in this way encourages, as is the case with Derrida, to slip into otherness (exaggerated identification, which is a temporary remedy against" identity distortion. Its manifestation is the equating of the young Jewish identity [self] with another [i.e. with French - A.W.], which he does not know properly. What is certain is that something of the highest importance 'comes from another', it has 'always' stayed there 'and' returns there [to self] with another [i.e. with French - AW], which is not properly known to him. What is certain is only that something of the highest importance 'comes from another', 'always' staying there 'and' returns there" (Farred 2016: 305). It is impossible in this article to discuss the source of Derrida's thinking about difference, but by quoting this short passage and referring the Reader to both Farred's and Derrida's (1998) texts, I suggest that it is personal experiences.
} 
is not hard not to notice that otherness violates the order of identity of the acting subject, which "may degenerate into disorder, but also may pass into another order; it may be different from what it is" (Waldenfels 2009: 15).

Thanks to the "work" of the difference, I reveal myself in my otherness - for myself I am only to read the meanings of otherness and assign them to myself as the future ones - not yet and not here - to the Other. But I also express myself as one whose strength I am not aware of as an Other. Only in the foreground is the relationship with the Other visible - also with myself as the Other, in the background it is invisible and unaware of me. It hides behind what is open, that is, my consciousness. As an acting subject, I sense myself and also act from the unconscious realm, which is as alive as the realm of consciousness ${ }^{16}$. The language of the unconscious self is acausal and alogical, therefore intuitive, instinctive, spontaneous and autonomous in the face of the will of the conscious self ordered by the Cogito. I cannot understand myself speaking out of unconsciousness through the prism of the Cogito language, but I can experience it (in the sense of experiencing which is primarily the feeling of being different in myself and of myself as different) when I surprise myself in speaking/expressing myself when I wonder at myself and amaze myself to the point of shock or admiration for myself: "Oh! Is it me?", “Oh! It is I 'yes', I think, I feel, act et cetera?". Also when my intuition is automatically turned on - which "speaks" to me through various signs: intuitions, revelations, images seen in my imagination. Speaking to myself out of unconsciousness, I make myself doubtful or make sure of myself - these are the poles between which the meanings of the relationship of the conscious acting subject with the Other and that me who "leans out" from the area of the unconscious extend. The awareness of oneself as the acting subject "clashes" with the effect of the "work" of the difference - with the otherness that we experience also in the unconscious field, beyond the possibility of grasping the conscious (conscious acting subject) from the conscious field.

Is then the confidence of the identity of myself as an acting subject grounded, usually expressed in a simple statement: I know who I am, why and for what I act? What and how is certain in me - in a subject different from that which I do not know (yet) and do not understand (yet), and which is also beyond my sphere of consciousness, although it is related to me?

The effect of the "work" of the difference, i.e. otherness and the response to it of the acting subject by reading its meanings and giving itself meanings as becoming Other, can be seen in two planes: the location of what is/took place in time and its blurring. The effect of the "working" difference may be located in an eventuality bordering on contingency, which I understand at this point as what might not be

\footnotetext{
${ }^{16}$ At this point, I refer to the concepts of Carl Gustav Jung, as well as post-Jungian conceptions of the human psyche (psychology of depth), at the base of which we find the assumption about the integrity of consciousness and the unconscious as dynamizing forces. I wrote more on this topic earlier (Walczak 2012).
} 
either. For example, I assign to the category of an event such an encounter with the presence of the Other, which - when it takes place - intensely moves the sensuality, stretched between the classical attitude to sanctity here: fascinozum et tremendum as defined by Rudolf Otto (1999). Such a meeting surprises with what is happening in it, or at least with an announcement of what may be happening in the acting subject, or rather in the subject, whose activity can radically change by changing the attitude towards itself, the Other, the world. This is a meeting, as a result of which you may stop speaking or even break with your previous statements. The point, however, is that meeting the presence of the Other is also a meeting that is "nonmeeting." This "non-meeting" is a breaking off of the relationship with the Other to the point of separation with him - an attitude to him as, for example, unknown and incomprehensible to the threatening status qua of the world known and understood by me. Such expressive meeting and post-factum "non-meeting" still remain a borderline experience in the biography of the acting subject - also with its changing meanings, for example through the prism of other meetings experienced and those that are only an expression. Although the experience of such a meeting and "non-meeting" with time is not so intense and the meanings assigned to them before and now may differ, they are present in the biography of the acting subject.

The "work" of the difference also has no location of its beginning. The point is not that something did not happen, but that, first of all, if something did, it was not given meaning at that time, because it took place, for example, in the ordinariness to which one is used to. Secondly, the "work" of the difference is still happening, so it is difficult to grasp its effect - for example, meeting the Other happens also when the Other is no longer in reality. Third, what is happening is not an event. New meanings are not so much given to what is, but to what even happens and functions in the existing meanings. Moreover, what is happening is part of the annals of permanent memory (it always is) and its oblivion (it never happened). Fourth, responding to otherness as a result of the "work" of difference takes place at a notat-this-time when the "work" of difference takes place. I have indicated four possible 'factual' reasons for the lack of 'work' location of the difference in the form of 'revealing' otherness. Not-at-this-time, which is also associated with not-in-thisspace, the "work" of the difference nevertheless lasts. There is no beginning of the change localized as an event - it is happening. Does this mean that the acting subject itself deprives itself of the possibility of a sense of unity and continuity, thanks to which it can declare to itself and to the Other: it is still me?

The "work" of the difference in the context of the identity of the acting subject reveals it as a plurality which, although it expresses itself in the first person singular - "this is I", creates its identity through various expressions/utterances which also relate to each other ${ }^{17}$. Being different does not mean that my identity

\footnotetext{
17 I believe that it is worth exploring the idea of abandoning the idea of a subject in favour of subjectivity (all "present" and "absent" but possible subjects). However, this requires a separate study.
} 
changes many times and diametrically, and that my "old" self no longer attests to me. The verticality of identity - the vertical direction of its formation (formation upwards) intersects with horizontality and with the extraction of horizontal directions (formation in breadth). The verticality of the identity of the acting subject, associated with the vertical direction, can be compared to its changes over time correlated with progressive changes. Then the identity as such would be the goal of the acting subject. After all, my identity is to testify to being subjectivity - to me acting. Identity is understood here as eidos - it is an autotelic value and as such constitutes the basis of the idea of self development: "taking" shape (cf. Kopaliński 1989: 139). Experiencing myself - experiencing myself as the acting I, at the same time I keep asking myself: "am I a worthy I?" On the other hand, the horizontality of identity, associated with the horizontal direction - can be compared to changes within it, located next to each other rather than above each other. Their diversity, on the one hand, and the non-constancy of the importance of their position in time on the other, make the horizontal dimension of identity dynamic. Then, experiencing myself, I ask: "What am I composed of?" In this way, the identity of the acting subject arises as a differentiating unity in the continuity of action. Unity - the unity of the self as an acting subject is therefore not the same self in time and space. Such an identity is what it becomes when it is immersed in what it has become in the indivisibility of me as its owner. With all ailments and imperfections.

The identity of the acting subject, with the Derridian différance inscribed in it, is not a stable basis for being that subject. It cannot also be talked about as substantial subjectivity. Ownership and closeness - I, having myself and thus being close to myself (present here now), am confronted with strangeness (as a "kind" of otherness) and distance and distance - with the I who I do not have myself, but create myself, the I "opposite" The other whom I am becoming, and is therefore still absent. I am an idiom beyond the final constitution of myself, which requires leaning over the railing of the known and obvious self - I am becoming myself. The non-constancy of the identity of the acting subject can be compared to the rhythm whose characteristic feature is repetition - leitmotif: being in a relationship with the Other, also with oneself as the Other, but multiple repetition. The "work" of the difference causes something different to be repeated every time - to a different being in a relationship with the Other. In being "opposite" to the Other, seeing and hearing the Other, I do not look at and listen to him in the same way. Also, when I see and hear another Other, I see and hear him differently. I have in me and not understood by myself the Other, whose relationship with another Other me, due to the "work" of difference, becomes a dynamic element of identity. The relationship between otherness and me as an acting and therefore relational subject is not selfevident in its meaning. One-sided positive connotations - otherness is the building block of my identity as an acting subject - are adjacent to those that also reveal the illusion of its certainty. 
The identity of the acting subject is not created only by himself, and he is not alone in justifying it, if only because his self is not/cannot be determined solely by its cause. In order to constitute an identity, this subject needs a multiplicity of different references to what is different - the other in himself. By shifting the meaning of difference from the outside to the inside of the acting subject and recognizing it as the primary prejudice of its emerging identity, I point to the significance of the invisible "moving" of this subject, which is not a condition for changes and changing its identity - it indicates their possibility, related to the ability to respond to the very "stir" itself.

\section{The genealogy of ethics of a subject acting as an "open" ending}

Let me start by quoting the words of Bernhald Waldenfels:

The question about the type of experience in which a stranger ${ }^{18}$ appears cannot be separated from the next question, namely, how do we meet this stranger. This question is accompanied by the motive of responsiveness, which is impossible to think without the ethical thread (Waldenfels 2009: 53).

Earlier, I wrote that I recognize the Other as long as he recognizes me. It is therefore about mutual recognition of being "opposite". Recognition does not yet "mark" being in a relationship with each other. The presence of the Other in the reality and me as the Other for him does not yet initiate a relationship with him on the second level - the relationship with him, also with me as the Other. Initiation begins with the "work" of difference and the emergence of and reference to otherness. Otherness hits the area of passive experience - through the Derridian separation it moves it and as if awaits an answer. "As if" must be treated as a mental shortcut - otherness begins in me, and this is the first "mute" answer on the part of the subject. There is otherness in me, even if this observation, also felt in the blink of an eye, was to take place too late, that is, it was distant from any factual event - being with the Other "opposite" and started with the "work" of the difference. What I am responding to is differentness, and precisely its feeling. Emmanuel Lévinas in Otherwise than Being or Beyond Essence ${ }^{19}$ writes, "Responsibility for another cannot begin with my commitment, with my decision" (Levinas 2000: 23).

\footnotetext{
18 The article consistently talks about being different and the Other. Waldenfels's strange/strangeness is perceived as the primary feeling of that, which of me - selfness, is beyond it, and more precisely - is not it.

${ }^{19}$ Lévinas's Otherwise than Being or Beyond Essence is treated as a constructive response to Derrida's criticism of his Totality and Infinity, where - according to Derrida - the encounter with the Other questions the identity of the Same.
} 
It takes root in the presence of the Other opposite me, and although Lévinas linked this presence with the call of the Other, he decided that the answer to this call comes from the presence of otherness in me - the voice of someone asking for an answer from me. Responding to otherness - responding to it, which Waldenfels calls responseveness ${ }^{20}$, is therefore secondary to the self-responding feeling of being different - responding to this experience. Waldenfels writes that answering "it does not begin with speaking, but with watching and listening", although it does not have to be consciously directed towards the otherness of my activities, nevertheless "even non-listening implies listening, not seeing - seeing" (Waldenfels 2009: 57). Answering can be compared to the primary sensory sensitivity to otherness, which allows one to hear the question: "How am I supposed to be with myself now?"21 I cannot fail to answer this question, because the lack of an answer is also the answer. Waldenfels writes about responsiveness:

The area of what is our own, without which no one would be that or who he is, we owe to coming out towards something strange that eludes us. This is what I call responsiveness. (...) Responsiveness goes beyond all intentionality, because entering into what happens to us is not exhausted in the meaningfulness, comprehensibility or truthfulness of what we give in response. (...) Responsiveness means such an "ability to answer" ("Antwortlichkeit"), which irrevocably precedes responsibility for what we do and say (ibidem: 42-43) 22 .

Answering and sharing answers are related (also on the lexical level) with responsibility, which I shall define here as a commitment to responding to otherness and the answer given to it (as a result of answering) ${ }^{23}$. Responsibility as an obligation is not located in a causal chain: here I am responsible for otherness, that is, I refer to it and therefore I am responsible to it. It is only when the otherness responds and the answer is given that its meanings appear for the subject himself, and therefore he feels responsible - he commits himself to the answer given by himself. This obligation is the primary phenomenon of the identity of the acting subject and allows the revealing of the meanings of the ethos that is being formed ${ }^{24}$.

\footnotetext{
${ }^{20}$ Norm Friesen (2014) analyses the responsiveness in Waldenfels's approach in more detail.

${ }^{21}$ At this point I refer to the well-known Tischnerian question: "How should I be with you?", Which for him was an ethical question par excellence.

${ }^{22}$ In a further statement by Waldenfels, we find an illustration of his position: "Even history lives by the fact that memories are awakened, and not simply gathered and processed like collected data" (ibidem: 43).

${ }^{23}$ I have written more on this topic elsewhere (Walczak 2011: 183-228). In this part of the article, I do not analyse and do not refer to the Derridian category of responsibility, very important to him, which was supported in his concept of ethical reading by the answer - the answer given to the text of the Other. "Responsible response" was for him a form of commitment to the text of the Other. Despite the lack of reference to the Derridian ethical reading, it is for me a background to the issues discussed in this part.

${ }^{24}$ Let us recall here, following Tischner, the Greek meaning of the word ethos: "Ethos is as much as 'the environment', 'home', the field of life for all living creatures" - a place where a plant can develop fully - it can bear fruit (Tichner 2006: 171).
} 
Answering and responding to the experience of being different are the crossing lines of the "invisible" beginning of discovering oneself as this acting subject. And when I speak, and therefore when I am an acting subject, otherness is already imported in the form of my answer to it and my responsibility as a commitment.

Could responsibility as an obligation be the principle of the rationale behind being an actor? In answering in the affirmative, I refer not so much to Heidegger's interpretation as it serves me to justify its link with the acting entity's obligation to respond to otherness. However, I shall start by quoting the words of Martin Heidegger himself: "that which is real in a given case has some reason for its reality. What is possible in a given case has some reason for its possibility. What is necessary in a given case has some reason of its necessity" (Heidegger 2001: 157). But such an approach to reason does not satisfy him, because reason here has a function of securing what exists and what is "counted" by reason, which in this way validates the existence of something. His counterpoint statement is: "being is called right. The principle of reason as a word about being can no longer want to say: being is right" (ibidem: 168). The principle of reason does not confirm any reason for being or being the being of something, it reveals the possible sense of being - "the principle of reason as a word about being (...) this strong word is a gentle word, it just conveys to us only the meaning 'being'" (ibidem: 171). The principle of reason is not based on the command "Why", but on the message "Because/During" and as a message it is a sign indicating the meaning of being. Heidegger recalls the words of Goethe: "Give up Why, hold on to Because" (ibidem: $170)^{25}$.

Referring to Heidegger's approach to the principle of reason, responding to otherness is focusing on finding ways for this response, in which the acting subject is able to respond to what is worthy of an answer ${ }^{26}$. Responsibility is a commitment to I as becoming the Other I am worthy of. This obligation becomes the principle of the reason for being an acting subject - I act not because I undertook to act, I act "because" the obligation is for me a message of the possible sense of action. As a principle, reason is "great, in the sense of something that is capable of much, that is capable of much, that is powerful" (Heidegger 2001: 171). It does not speak of the command of the "Why" command, but of "Because" which "directs reason in essence (...) For it also points to the essence of being" (ibidem: 170).

\footnotetext{
${ }^{25}$ Heidegger writes about the word "why" as follows: "Why" does not give me peace, does not offer a stop, does not provide support (ibidem: 169). Cf. Pilate, presenting his own proposal of presenting the subject, who writes about the reason for acting: "Right is a premise of a specific judgment - a component of an act of will. It is therefore a necessary condition for human action (...) it is epistemic and logical (...). It is not the same as the motive or the wake-up call, but it is a component of the motivational system and the rational core of the psychological mechanism that causes actions. In the latter sense, reason is placed in time, namely, it is prospective" (Piłat 2016: 50). We are used to this interpretation of the arguments. The principle of right presented in Heidegger's article has a different meaning.

${ }^{26}$ This sentence refers to Heidegger's question about the "state" of the essence of modern man: "Are we not obliged to find ways in which thinking can respond to what is worthy of thinking, instead of passing by what is worthy of thinking, enchanted by calculating thinking" (Heidegger 2001: 173).
} 
I shall juxtapose responsibility as an obligation, pointing to the "essence of being" as an acting subject, with Ricoeur's keeping the word given in the promise, in order to be able to grasp its specificity better. The essence of promising here is to keep your word that the Other - and therefore I as the emerging Other, can count on me (Ricoeur 2005: 567). Let us return to the question: "How am I supposed to be with myself now?" - or how to be responsive to being different with oneself as a result of the "work" of the difference? How am I to be with myself as becoming Other? If I, as the Other, count on myself, then I give myself the assurance that I shall not fail myself as the Other I am becoming. Honouring oneself as becoming Other, which for Ricoeur is a "reflective moment of willingness to 'live a good life"', is combined with caring as "benevolent spontaneity" for the quality of becoming Other and favouring it, and this is because that it was faced with the fragility of being what I become as the Other (ibidem: 315, 319). And only then am I "he-whois-himself-and-also-other" (ibidem: 591).

Referring to Waldenfels's considerations about responding to strangers (2009: 53-64; cf. Friesen 2014), responding to otherness is an ability of the subject, which I associate with the ability to respond and be responsible in the sense of: being obliged to provide oneself responses to the perceived/felt effect of the "work" of difference - otherness. And when it comes to ability, not everyone, and not always - not everyone here right now - can answer and give answers. The difference cannot be noticed - as a result of the "work" the difference is usually in the seed form and its meanings are revealed over time. On the other hand, being different can paralyze, and the response may be, for example, to withdraw from an action or lose oneself in $i^{27}$. And this means that responsibility as an obligation is a contingent phenomenon of the emerging identity of the acting subject, and - like the effect of the "work" of the difference - it might not exist, or it might be different to the one here now.

In conclusion, the responsiveness that I borrowed from Waldenfels ${ }^{28}$ and responsibility as an obligation and related to Heidegger's reason for action and Ricoeur's keeping his word given in the promise are constitutive components of the genealogy of the ethics of the subject acting as an ethics of the first person, i.e. ethics from the self - the author of everyday action: in being-in-the-world day by day. The subject acting "simply" is anchored in ethics - he is not supposed to act ethically, but the ethics of becoming one is a condition of how he works. Usually, ethical action is associated with responsible action, that is, one that is now appropriate action and for which the acting subject bears the consequences. In the context of the subject of the article, it should be noted that responsible action is primarily about assuming and accepting consequences before and during the

\footnotetext{
${ }^{27} \mathrm{Cf}$. polar manners of being in the face of borderline experiences, e.g. experiencing the death of a loved one - on the one hand, stupor in experiencing life up to withdrawing from it, on the other hand, immersion in the currents of life to the point of choking on them.

${ }^{28}$ This, in turn, points to borrowings from Kurt Goldstein, Mikhail Bakhtin, Emmanuel Lévinas, and Maurice Blanchot (Waldenfels 2009: 54-55).
} 
action. In reference to Waldenfels, however, there is a certain significant prejudice against accountability for what one thinks, says and does et cetera. It is precisely the "ability to give answers" (Waldenfels 2009: 54), which I associate with a sensitivity to the quality of being who I am becoming as a subject of action, which is also a relational subject.

So what is ethics in the context of these considerations? It is a way of becoming who the acting subject not so much is, as what is still in front of him. Then the effect of the "work" of the difference comes to light, that is, the reference to otherness, which constitutes being with the Other and with oneself as the Other. The reference to otherness, being in a relationship with it, usually lasts a span of time (even if the relationship itself has already been broken), and when constituting itself over time, it becomes an expression of further references to it and its readings of otherness. And as Waldenfels writes, "each birth, in which a new world opens, has features of rebirth, because the new can only be grasped later" (ibidem: 62). I shall supplement this statement with that of Józef Tischner on the ethical experience. For him, it awakes "when a person discovers that he is standing in front of a similar human being" (Tischner 2006: 170). Then the question arises (may arise) - "How am I supposed to be with you as the Other?". So, how am I supposed to be with myself as becoming Other, remaining temporarily at home and only then embracing ...? How am I with myself as becoming Other? Being still in front of myself, I am in front of the Otherness, also myself as becoming the Other, where the ethicality of becoming is not a superstructure but a foundation.

\section{References}

Bachelard G. (2000) Filozofia, która mówi nie. Esej o filozofii nowego ducha w nauce, trans. J. Budryk, Gdańsk, Słowo/obraz/terytoria.

Barbaras R. (2017) Trzy znaczenia pojęcia „żywe ciało”, trans. J. Migasiński in: Główne problemy współczesnej fenomenologii, J. Migasiński, M. Pokropski (eds.), Warszawa, Wydawnictwa Uniwersytetu Warszawskiego: 80-96, https://doi.org/10.31338/ uw. 9788323524397

Buber M. (1992) Ja i Ty. Wybór pism filozoficznych, trans. A. Doktór, Warszawa, Państwowe Wydawnictwo Naukowe.

Burzyńska A. (2013) Dekonstrukcja, polityka i performatyka, Kraków, Universitas.

Cichowicz S. (1975) Bez złudzeń, „Teksty: Teoria Literatury, Krytyka, Interpretacja”, no. 3 (21): 68-74.

Choińska B. (2014) Podmiot i dyskurs w świetle myśli wybranych przedstawicieli poststrukturalizmu francuskiego, Kraków, Universitas. 
Dąbrowski K. (1979) Dezintegracja pozytywna, Warszawa, Państwowy Instytut Wydawniczy.

Derrida J. (1978) Różnia, trans. J. Skoczylas, J. Cichowicz in: Drogi współczesnej filozofii, M. J. Siemek (ed.), Warszawa, Czytelnik: 374-411.

Derrida J. (1996) Psyche. Odkrywanie Innego, trans. M. P. Markowski in: Postmodernizm. Antologia przekładów, R. Nycz (ed.), Kraków, Wydawnictwo Baran i Suszyński: 81-107.

Derrida J. (1998) Jednojęzyczność innego, czyli proteza oryginalna, trans. A. Siemek, "Literatura na Świecie”, no. 11-12: 24-111.

Derrida J. (1999) $O$ gramatologii, trans. B. Banasiak, Warszawa, Wydawnictwo KR.

Derrida J. (2004) Pismo i różnica, trans. K. Kłosiński, Warszawa, Aletheia.

Derrida J. (2007) Pozycje. Rozmowy z Henri Ronsem, Juliq Kristevq, Jean-Louis Houdebinem i Guy Scarpetta, trans. A. Dziadek, Katowice, Fa-art.

Farred G. (2016) 'Nostalgieria': Derrida przed i po Frantzu Fanonie,"Ethics in Progress", Vol. 1, Issue 7 Polish Supplement, Vol. 1, no. 1, Art. \#19: 299-318, https://doi.org/10.14746/eip.2016.1.19

Friesen N. (2014) Waldenfels' Responsive Phenomenology of the Alien: An Introduction, "Phenomenology \& Practice": 1-11, https://doi.org/10.29173/pandpr20640

Fromm E. (1994) Niech się stanie człowiek. Z psychologii etyki, trans. R. Saciuk, Warszawa-Wrocław, Państwowe Wydawnictwo Naukowe.

Glinkowski W. (2011) Człowiek - istota spoza kultury. Dialogika Martina Bubera jako podstawa antropologii filozoficznej, Łódź, Wydawnictwo Uniwersytetu Łódzkiego.

Heidegger M. (2001) Zasada racji, trans. J. Mizera, Kraków, Wydawnictwo Baran i Suszyński.

Kopaliński W. (1989) Słownik wyrazów obcych i zwrotów obcojęzycznych, Warszawa, Wiedza Powszechna.

Kruszelnicki M. (2008) Drogi francuskiej heterologii, Wrocław, Wydawnictwo Naukowe Dolnośląskiej Szkoły Wyższej.

Lacan J. (2004) Le séminaire, Livre X, L'angoisse, Paris, Seuil.

Lévinas E. (2000) Inaczej niż być lub ponad istota, trans. P. Mrówczyński, Warszawa, Fundacja Aletheia.

Marzec A. (2011) Différance Derridy. Czy błąd daje się (wy)tłumaczyć?, „Przekładaniec", no. 24: 263-280. 
Męczkowska A. (2006) Podmiot i pedagogika: od oświeceniowej utopii ku pokrytycznej dekonsktrukcji, Wrocław, Wydawnictwo Naukowe Dolnośląskiej Szkoły Wyższej Edukacji TWP we Wrocławiu.

Nycz R. (2017) Kultura jako czasownik. Sondowanie nowej humanistyki, Warszawa, Wydawnictwo Instytutu Badań Literackich PAN.

Otto R. (1999) Świętość. Elementy irracjonalne w pojęciu bóstwa i ich stosunek do elementów racjonalnych, trans. B. Kupis, Warszawa, Wydawnictwo KR.

Piłat R. (2016) Podmiotowość jako relacja osoby do jej własnej przyszłości in: Spór o podmiotowość. Perspektywa interdyscyplinarna, A. Warmbier (ed.), Kraków, Księgarnia Veldemicka: 37-60.

Potępa M. (2004) Fenomenologia faktycznego życia. Martin Heidegger, Warszawa, Genessis.

Reut M. (2010), Narracja i tożsamość: pytanie o "ja" jako problem etyczny i pedagogiczny, Wrocław, Wydawnictwo Naukowe Dolnośląskiej Szkoły Wyższej.

Ricoeur P. (2005) O sobie samym jako innym, trans. B. Chełstowski, Warszawa, Wydawnictwo Naukowe PWN.

Surma-Gawłowska M., Zawadzki A. (ed.) (2015) Myśl mocna, myśl słaba. Hermeneutyka włoska od połowy XX wieku. Antologia tekstów, Kraków, Księgarnia Veldemicka.

Szkudlarek T. (2008) Dyskursywna konstrukcja podmiotowości („puste znaczq̨ce” a pedagogika kultury), "Forum Oświatowe", special issue: 125-140.

Szkudlarek T. (2012a) Ryzyko tożsamości in: W. Łukaszewski, D. Doliński, A. FilaJankowska, T. Maruszewski, A. Niedźwieńska, P. Oleś, T. Szkudlarek, Tożsamość: trudne pytanie kim jestem, Sopot, Smak Słowa: 127-143.

Szkudlarek T. (2012b) Tożsamość in: M. Cackowska, L. Kopciewicz, M. Patalon, P. Stańczyk, K. Starego, T. Szkudlarek, Dyskursywna konstrukcja podmiotu: przyczynek do rekonstrukcji pedagogiki kultury, Ars Educandi - Monografie, no. 3, Gdańsk, Wydawnictwo Uniwersytetu Gdańskiego: 303-356.

Szkudlarek T. (2017) Polityczność, tożsamość i humanistyczna produkcja znaczeń, “Chowanna", no. 1 (48): 57-70.

Tischner J. (2006) O człowieku. Wybór pism filozoficznych, Wrocław-Warszawa-Kraków, Zakład Narodowy im. Ossolińskich - Wydawnictwo.

Walczak A. (2011) Spotkanie z wychowankiem. Ku tożsamości ipse pedagoga, Łódź, Wydawnictwo Uniwersytetu Łódzkiego. 
Walczak A. (2012) Tworzenie wiedzy pedagogicznej z perspektywy archetypowych wymiarów kobiecości i męskości, „Ars Educandi”, no. IX: 152-174, https://doi.org/ 10.26881/ae.2012.09.10

Waldenfels B. (2009) Podstawowe motywy fenomenologii obcego, trans. J. Sidorek, Warszawa, Oficyna Naukowa.

Warmbier A. (2019) Tożsamość, narracja i hermeneutyka siebie. Paula Ricoeura filozofia człowieka, Kraków, Universitas.

\section{(Re) conceptualisation de la différence dans le contexte de l'identité du sujet agissant}

\section{Résumé}

L'article traite de l'identité du sujet agissant - qui en tant que tel (c'est-à-dire le sujet qui s'exprime) étant toujours en relation avec l'autre (et en référence à la philosophie de l'homme de Paul Ricoeur aussi avec lui-même comme autre) - est un sujet relationnel. La catégorie de « différence » s'inscrit dans le processus de construction de son identité. Elle est habituellement associée à la différenciation des autres - y compris de soi-même, par exemple, à une période antérieure. Et ainsi comprise, elle indiquerait une frontière entre le sujet et les autres (et lui-même comme un autre) et en même temps c'est elle qui « garderait » le sujet dans le « régime » de son identité.

Dans l'article, la catégorie de différence, qui s'insinue dans la lecture des significations de la différance de Jacques Derrida, est déplacée de l'extérieur vers l'intérieur du sujet agissant, alias relationnel, et présentée comme une antériorité primaire de son identité en train de se construire. Il s'agit de l'importance de «l'agitation » invisible de ce sujet, qui n'est pas en soi une condition de changement ni de modifications (dans) de son identité - elle indique leur possibilité, impliquant la capacité de répondre à « l'agitation » elle-même.

C'est ainsi que l'on arrive à la généalogie de l'éthique de soi en tant que sujet agissant alias relationnel, où la différance derridienne se manifeste par l'étalement, la pause, l'écart temporel et spatial - entre l'endroit où quelque chose est ici (ce que / qui je suis ici) et ce qui n'est pas encore quelque part (ce que / qui je ne suis pas là).

Ce n'est que dans cette optique que l'on peut révéler une altérité avec laquelle « il faut faire quelque chose», aussi parce que c'est elle qui fait la différence dans le domaine de l'identité du sujet agissant, alias relationnel, en préfigurant une éventuelle modification. Toutefois, l'identité du sujet agissant, avec la différance de Derrida qui y est inscrite, ne constitue pas de base stable pour être un tel sujet.

C'est pourquoi l'éthique réactive devient si importante, ses principales catégories sont la responsabilité en tant que réponse et engagement liés à l'interprétation de Heidegger de la raison d'action et au respect, chez Ricoeur, de la parole donnée dans la promesse. Cela signifie que le sujet agissant, alias relationnel, est «tout simplement" ancré dans l'éthique - il n'est pas pour autant destiné à agir éthiquement mais l'éthique de devenir un sujet agissant est une condition de la façon dont il agit. 


\section{(Re)konceptualizacja różnicy w kontekście tożsamości podmiotu działającego}

\section{Streszczenie}

Artykuł traktuje o tożsamości podmiotu działającego, który jako taki (czyli podmiot wypowiadający się) jest zawsze w relacji z Innym/-i (a odwołując się do filozofii człowieka Paula Riceoura - również z samym sobą jako Innym) - jest podmiotem relacyjnym. W proces tworzenia się jego tożsamości wpisana zostaje kategoria „różnicy”. Zwyczajowo jest ona kojarzona z odróżnieniem się od innych - również od siebie samego, np. z wcześniejszego okresu. Tak pojmowana wskazywać by miała na granicę między podmiotem i innymi (również nim samym jako innym) i zarazem to ona „trzymałaby” podmiot w „ryzach” jego tożsamości. W artykule kategoria różnicy - posiłkując się odczytaniem znaczeń różnicy - différance Jacquesa Derridy, zostaje przesunięta z zewnątrz do wewnątrz podmiotu działającego vel relacyjnego, ujmując ją jako prymarną uprzedniość jego tworzącej się tożsamości. Mowa jest o znaczeniu niewidocznego „poruszenia” tegoż podmiotu, które samo w sobie nie jest warunkiem zmiany i zmian (w) jego tożsamości - ono wskazuje na ich możliwość, wiążąc się z umiejętnością odpowiedzenia na samo „poruszenie”. W ten sposób dochodzi się do genealogii etyki siebie jako podmiotu działającego vel relacyjnego, gdzie Derridiańska różnica uobecnia się poprzez rozsunięcie, przerwę, odstęp czasowy i przestrzenny - między tym, gdzie coś jest tu (czym/kim jestem tu), a czego jeszcze nie ma gdzieś (czym/kim nie jestem tam). Tylko w tej optyce może ujawniać się inność, z którą „trzeba coś począć”, także dlatego, że to ona wprowadza różnicę w obszar tożsamości podmiotu działającego vel relacyjnego, zapowiadając możliwą jej zmianę. Niemniej, tożsamość podmiotu działającego, z wpisaną weń Derridiańską różnicq, nie jest stabilną podstawą bycia tym podmiotem. Dlatego tak ważna staje się etyka responsywna, której kluczowymi kategoriami jest odpowiedzialność jako odpowiadanie i zobowiązanie powiązane $\mathrm{z}$ Heideggerowską wykładnią racji działania oraz Ricoeurowskim dotrzymaniem słowa danym w obietnicy. To oznacza, że podmiot działający vel relacyjny „po prostu” jest zakotwiczony w etyce - nie tyle ma działać etycznie, co etyka stawania się nim jest warunkiem tego, jak działa.

\section{To cite this article}

Walczak A. (2021) (Re)conceptualizing Difference in the Context of the Acting Subject's Identity, „Nauki o Wychowaniu. Studia Interdyscyplinarne” 2(13), 88-108, https://doi.org/10.18778/2450-4491.13.07 